\title{
The Plight of The Current Our Country University Counselors Work and The Way Out
}

\author{
Wang $\mathrm{Yu}$ \\ Environmental Management College of China \\ Qinhuangdao, China
}

\begin{abstract}
The current counselors in colleges and universities is faced with is the unrealistic demands for professional knowledge, career development path of embarrassing, a multiple role conflict, leadership and management class authority and responsibility generalization, etc. We believe that universities should be taken to expand, to improve the quality of instructor development path, pay attention to build team work mode, clear responsibilities of instructors and other measures to work out of the plight of the instructor.
\end{abstract}

\section{Keywords-Counselors Work Trouble}

Since the party central committee and the state council on further strengthening and improving ideological and political education of college students opinions were found (document no. 16 [2004]) and the ministry of education "on strengthening the construction of institutions of higher learning counselor teacher team opinion" issued, since our country entered the stage of rapid development of headteachers counselors working as a core part of the university students' work, already broke through the category of mere political guidance and students' ideological and political education, psychological counseling and career guidance, career planning, daily management, and even academic counselling is equal to one. At the same time, the growing of headteachers' construction, the counselor work unprecedented attention, counselors work quality have a certain degree of increase. But then came the counselor work has added to the complexity and contradiction, cause the counselor work of many difficulties, these difficulties hindering the further development of the counselor and the continuous improvement of quality, limit the counselor professional development itself, and the requirements of a professional, experts from the counselor team away. To the plight of the current college counselors work, therefore, analysis and research, find out the methods and paths.

\section{THE DIFFICULTIES FACING COLLEGE COUNSELORS}

\section{A. The counselor professional knowledge facing the unrealistic demands}

"Role integration is a significant feature of counselors in colleges and universities, each instructor is responsible for not only students' ideal faith and ideological and moral education, and to carry out professional learning, mental health, career planning and guidance, bear the task of the comprehensive." the task of the comprehensive requirements counselor comprehensive professional knowledge. In terms of existing professional knowledge background of counselors, although structure has improved in recent years, but still there are only a few instructors from the ideological and political education, psychology, pedagogy, sociology, or related to trains the student to become professional; Every counselor even if, on the other hand, have a certain professional knowledge, but still very lacking in comprehensive ways. Or even the counselor all aspects are a little bit, but may also be less than their students in depth, in fact it is hard to talk to students in terms of professional knowledge. And professional knowledge of the comprehensive requirements of instructors is impractical, not only beyond the ability of counselors, and society also give the counselor's political and social status does not match.

\section{B. The career development path of embarrassment, which leads to the counselor team is not stable}

Professionalization of headteachers and experts in academic and higher education is a common consensus of the administrative department. But ordinary institutions of higher learning counselor team construction rules pointed out: "higher school counselors is an important part of teachers' team and management team, has the dual identity of teachers and cadres." Although there are some truth to this kind of system design, but also clear counselors may be defined as a transitional role, don't mean to encourage counselors lifetime engaged in the work. So many colleges and universities on the basis of the new teachers hired as a counselor, a few years later these teachers has become specialized professional class teacher, is no longer a student counselor; Can foster "or" auxiliary, the counselor's career development is to do special administrative management cadre, also no longer do counselor. It's hard to cultivate the counselor strong professional sense of belonging, but temporary concept formation, destabilize the team and student counseling work of fracture, is ultimately nobody would make college counselors work as a career to do; At the same time the counselor work for is always new people doing in a process of adaptation, groping for a long time, it is difficult to develop the real expert instructors. It seems that a professional and expert counselor team is difficult to achieve, thus it is not easy to assure the quality of the instructors work.

\section{In a multiple role conflict, caused the counselor multiple personality}

"Counselor plays a student in the work of educators, administrators, coordinator, server, bosom friend, the executor of the school system and student advocates of 
role, and even play a role of the higher education researchers." These roles are faced with different pressure, at the same time there are multiple conflict between these roles, for example, the manager role conflict with friends role, leader role conflict with server role, the school system executive role with students interests conflict between maintainer role, etc. And these roles often need to play in dealing with the same thing at the same time, this leads to the counselor career is much more difficult than actor, because a person is unlikely to play multiple roles at the same time in the real world; Even role playing time on the order, due to the limited time interval, the counselor is also difficult to when needed to convert the role, which tends to push some of the students ideological education and administrative punishment to the point of hard to everything. And the idea of multiple roles can also make the counselor to form multiple personalities, the counselor duplicity when talking or doing things, different from before and after, this not only affects the counselor's accomplishment and image, and seriously affect the quality of the instructors work.

\section{Lack of authority, leadership, management class education effect is difficult to produce}

Education needs to authority, famous French sociologist Emile durkheim pointed out: "education activity is a kind of authority." There is no authority, education is difficult to produce the result that educators have come to expect. And the formation of authority depends mainly on two factors: the institutional factors and personal factors. The reality is, however, on the one hand, from the system level given the authority of the counselors in colleges and universities. Colleges and universities is a hit from the instrumental rationality, utilitarianism, the generation of institutional authority is with counselors have and can give students resources proportional to the. For now, however, the bottom layer of counselors at colleges and universities, and do not have what students need of resources, and many instructors use their knowledge of the only resource capacity is also very limited, this makes the institutional authority is difficult to produce. , on the other hand, in terms of personal factors, our country college counselors work is comprehensive, the counselor's own professional knowledge and experience experience, in the face of what they should play multiple roles, deal with different problems or some of the procedural professional daily affairs is ability very cramped. Such personal factors such as the counselor knowledge, expertise and personality charm is not able to play a role of authority. This leads to the counselor in class's and grade's leadership and management will encounter greater resistance, make the education effect is difficult to produce.

\section{E. Duties generalization, cause disorder counselors work and life}

The ordinary institutions of higher learning counselor team construction regulations in article 5 of the provisions of the eight aspects of the role of university counselors, but in the real work, counselor job extends far beyond the prescribed scope. In fact, all work related to the students in colleges and universities is to counselor to implement. This is what some experts to do the image of the parable: "the top one thousand line, here a needle." The instructor responsibilities generalization of cause by some transactional work day and night, on holiday, not only have no time and energy to achieve the ordinary institutions of higher learning counselor team construction regulations in article 4 "active learning and mastering the theory and method of ideological and political education, constantly improve the level of skills and work; work on a regular basis to carry out the relevant investigation and research, analysis of objects, and the change of working conditions, adjust work ideas and methods" such as requirements; And makes the counselor's work and life are not systematic, long-term in a state of disorder. In this way not only hinder the counselor professional development itself, even for the counselor's physical and mental health.

\section{THE CURRENT WORKING WAY OUT OF TROUBLE}

\section{A. Develop counselor development path}

Counselor professional development system design although has certain rationality, but also to a certain extent encouraged the counselors strive and achieve the goal that do not do the counselor, on the other hand the counselor in the career development will be subjected to many obstacles. On the title assess, for example, although the counselor at the system level can be evaluated as the lecturer, associate professor, professor, but in actual operation, the counselor will encounter such as specialty and application specialist mismatch, or of the work and learning professional mismatch, or other related scientific research can not meet the requirements and other aspects. Therefore, we believe that the counselor in addition to the development of management cadres, full-time teachers, should also implement a contingent of professional counselors and professionalization, opening the counselor as "counselors" life-long career development path, make its can be implemented on the counselor post yourself, let oneself recognized for his work, rather than one thousand ways to successfully transferred to gain recognition, to prove and realize their value. Such ability may remove the counselor transitional nature of the work, to a greater degree to guarantee the stability of the team after years of construction, can form a real bring together, age, professional structure reasonable counselor team.

\section{B. To improve the quality of the counselor}

Instructor own quality is the basis of the quality of work. Therefore, to do a good job in college students must have a high quality of the counselor team. Highly qualified instructors are more likely to become the authority in class management, on the one hand, on the other hand in dealing with the problems in the work also can have higher efficiency. Build high-quality counselor team should obtain from the following several aspects: (1) specification counselor entrance, should be strictly in accordance with "the central committee of the communist party of China, the state council on further strengthening and improving ideological and political education of 
college students opinions (found no. 16 [2004]) and the ordinary institutions of higher learning counselor team construction regulations requirements to filter and employment counselor. (2) should intensify the counselor training, on the basis of the current college counselor training in rotation increased training and batch size, at the same time to extend the time of training, make the further development of counselor training. (3) the counselor quality improvement, counselors should take the initiative to take time out for university students' ideological and political work related topics of investigation and study, at the same time pay attention to broaden our knowledge, breaking through any limits from professional strengthen self-improvement theory attainment, really as a career counselor work to do.

\section{Build team work mode, character decomposition, avoid role conflict}

Most colleges and universities of counselors individual work mode has many shortcomings, is not conducive to a contingent of professional counselors and professional, but also not conducive to the sustainability of counselor work. While team working mode can to a certain extent, to avoid these disadvantages. Instructor team working mode is to point to in the student work in the form of a team responsible for fixed or grade students professional counselling work, team members, according to the division of roles and responsibilities of the student work is responsible, to cooperate with each other, complement each other, rather than as a counselor corresponding to a class or class of students, and shall be responsible for all the students affairs work mode. instructor team working mode can let share the different roles in the work, assume different responsibilities, so as to share the role stress. At the same time, the counselor team working mode can also be of class management authority form groups, rather than a single counselor in the face of numerous students, in world outlook, the outlook on life, values conflict potential stretch solitary. And the counselor team working mode can also assign roles and responsibilities, according to the counselor's expertise is conducive to the counselor on what they are good at professional sustainable development.

D. Clarify the counselor responsibilities, avoid the counselor was irrelevant matters

The area of responsibility of the current college counselors is unclear, or has long been beset by student dormitory health and other daily administrative work, resulting in their relationships with students "dislocation", in the aspects of students' ideological education and psychological counseling "absence", in the aspect of students' self-management "offside", and make the counselors don't have the time and energy to focus on their own physical and mental health and professional development, which greatly affect the quality of the instructors work. So universities should according to "ordinary institutions of higher learning counselor team construction regulations request, let the counselor to undertake to the student ideological and political education, psychological counseling, academic counseling, career guidance and so on essential work. To really improve the students' ideological and political quality, resolve the contradiction of the students, help students healthy growth, and guide their successful employment and continuous professional development, their real success.

Instructor work is facing many difficulties, improve the work quality of counselor's own efforts alone is not enough, the most fundamental is the need to solve the problem from the system level. Only really pay attention to various colleges and universities, reform continuously, continuous innovation work mode, vigorously promotes the counselor team construction, pay attention to improve the quality of counselors, can help college students set up the correct world outlook, the outlook on life, values, the firm faith, to establish under the leadership of the communist party of China walk the road of socialism with Chinese characteristics and realizing the great rejuvenation of the Chinese nation's common ideal; To actively guide the student to continuously pursue higher goals, make them in advanced molecular sets up the lofty ideal of communism, to become qualified builders and successors to the cause of socialism with Chinese characteristics, to achieve a "Chinese dream" in the minds of each and every one.

\section{REFERENCE}

[1] Luo Gong profit; Guang-ming nie. Chen gang of counselors in universities in China is seen in international comparison role (07) 2007

[2] He Zhiming construction of college counselor team work mode 2010 (30)

[3] Chun-yan dong; Alan seigrist; NiuZhenFu role positioning of university counselors to explore $2007 \quad$ (02) 